\title{
Preliminary Studies on the lodine Content of some Marine Algae from Coastal Areas of Jaffna Peninsula
}

\author{
Rajeswary Mageswaran and S. Sivasubramaniam \\ Department of Chemistry, University of Jaffna, Jaffna, Sri Lanka \\ (Date of receipt: 20 February 1983) \\ (Date of acceptance: 20 September 1984)
}

\begin{abstract}
The iodine content of twenty seven species of marine algae collected from different coastal regions of the Jaffna Peninsula was determined. Of the species analysed, Gracilaria opuntia (1277 ppm), Gracilaria crassa (889 ppm) and Turbinaria ornata $(810 \mathrm{ppm})$ have relatively high iodine contents. The iodine content of Gracilaria opuntia is comparable with the amount of iodine present in caliche deposits $(1500 \mathrm{ppm})$ in northern Chile which is the principal source of iodine.
\end{abstract}

\section{Introduction}

Iodine is considered ${ }^{9}$ as one of the essential elements for the proper functioning of the hormones of human and animal thyroid glands. In many parts of the world simple goitre develops because of deficiency of iodine in water or food supply. An iodine deficient goitrous mother may give birth to a cretinous baby 9 because the foetus requires an adequate secretion of thyroxine during the later stages of pregnancy. Thyroxine is formed ${ }^{9}$ by the reaction of tyrosine with iodine.

To prevent simple goitre a dietary iodine intake of $100-200 \mu_{\mathrm{g}}$ daily9 is required. In places where manioc is used as a part of the diet the daily intake of iodine should be greater than the normal requirement. It is believed that cyanide in the manioc is converted to thiocyanate in the body which apparently displaces iodide from the reaction site. All iodine is converted to iodide in the gut. ${ }^{9}$ Normally iodine is supplied from water.

In some places iodine content of water may not be enough to meet daily requirement of iodine. Seaweeds are good sources to meet dietary requirements. of iodine. Goitre disease caused by iodine deficiency is less prevalent in countries. where marine algae form a part of the diet.1, ${ }^{7}$

The iodine has wide and varied uses and is of high demand. Attempts are being made by various workers and companies to extract iodine from various natural sources. Caliche deposits in northern Chile are the principal sources for the production of iodine. ${ }^{1}$ In Japan, Norway, France and Russia, iodine is extracted in small amounts from seaweeds.6, ${ }^{6}$ Valuable data on the iodine content of marine algae occurring in different parts of the world are available. ${ }^{3}, 5$ But information on the iodine contents of the species of algae from Sri Lankan coastal area. is not available. Therefore as an initial study, the amounts of iodine present in twenty seven species of green, brown and red algae collected from Jaffna coastal areas were estimated. 


\section{Experimental Methods and Materials}

The localities and habitats of the algae studied are given in Table 1. The freshly collected seaweed samples were washed free from extraneous matter and air dried at room temperature under fans. The air dried samples $(30-50 \mathrm{~g})$, weighed accurately, were dried in an oven at $110^{\circ} \mathrm{C}$ to constant weight and the moisture contents determined. The oven dried samples were ground and the iodine contents were estimated by the alcoholic potash $\operatorname{method}^{2}$ as follows:

Accurately weighed powdered samples $(5-10 \mathrm{~g})$ were refluxed with alcoholic potash $(10 \%, 30-60 \mathrm{ml})$ for 24 hours, evaporated and ashed at $500^{\circ} \mathrm{C}$. The water extract of the ash was acidified, oxidised with bromide and titrated with standard sodium-thiosulphate.

\section{Results and Discussion}

The results of analysis (carried out in triplicate) are given in Table 2. This table also gives the corresponding values for unwashed samples for a few species.

The above results show that of those species investigated, Gracilaria opuntia, Gracilaria crassa and Turbinaria ornata have reasonable amounts of iodine. To prevent simple goitre a dietary iodine intake of $100-200 \mu \mathrm{g}$ daily is sufficient. Therefore a vegetarian can easily get the required amount of iodine from properly processed marine algae.

The most important natural source, caliche deposits, found in Northern Chile which exports iodine to all parts of the world contains $0.15 \%$ (1500 ppm) of iodine1, Gracilaria opuntia has comparable amount of iodine (1277 ppm), Gracilaria crassa $(889 \mathrm{ppm})$ and Turbinaria ornata $(810 \mathrm{ppm})$ also have fairly large amounts of iodine. These three species would prove to be of commercial value.

Out of the three areas investigated marine algae from Mandaitivu coastal area have more iodine. It is significant that the sea water from this area has more iodine compared to the other two areas (Table 3). The iodine contents of Ulva lactuca, Codium species and Sargassum species are nearly the same as those reported ${ }^{3}$ for the same species from the Gujarat coast of India (Table 4).

\section{Conclusion}

The amount of iodine present in certain species (e.g. Gracilaria opuntia, Gracilaria crassa, Turbinaria ornata) of marine algae from coastal areas in the Jaffna Peninsula is comparable with the most important natural source, caliche deposits. These seaweeds could be exploited for the commercial extraction of iodine. Several other species have reasonable amounts of iodine and these could be used in the manufacture of fortified cattle leed and for preparation of high iodine food items for human consumption. 
TABLB 1. Localities and Habitats of the algae

\begin{tabular}{|c|c|c|}
\hline Species & Locality & Habitat \\
\hline 1. Gracilaria opuntia & Mandaitivu & Muddy lagoons \\
\hline 2. Gracilaria edulis & Mandaitivu & Protected inshore lagoons \\
\hline 3. Gracilaria crassa & Mandaitivu & Lagoon, erect tree like \\
\hline 4. Gracilaria confervoides & Keerimalai & Calcareous reef \\
\hline 5. Laurencia obtusa & Mandaitivu & Lagoon, attached by small discs \\
\hline 6. Jania natalensis & Mandaitivu & Lagoon, attached \\
\hline 7. Hypnea musciformis & Mandaitivu & Protected inshore lagoon \\
\hline 8. Acanthophora delile & Mandaitivu & Lagoon \\
\hline 9. Centroceras clavulatum & Mandaitivu & Lagoon, attached \\
\hline 10. Gelidiella acerosa & Mandaitivu & Lagoon, erect prostrate \\
\hline 11. Padina pavonica & Mandaitivu & Lagoon, attached \\
\hline 12. Turbinaria ornata & Mandaitivu & Lagoon, attached \\
\hline 13. Pocockiella variegata & Nainativu & Inshore waters \\
\hline 14. Stoechospermum marginatum & Mandaitivu & Lagoon, attached \\
\hline 15. Cystophyllum muricatum & Mandaitivu & Lagoon, attached \\
\hline 16. Dictyota species & Mandaitivu & Lagoon, attached \\
\hline 17. Sargassum tenerrimum & Mandaitivu & Lagoon, attached \\
\hline 18. Sargassum polycystum & Mandaitivu & Lagoon, attached \\
\hline 19. Hormophysa triquetra & Mandaitivu & Lagoon, attached \\
\hline 20. Struvea anastamosans & Mandaitivu & Lagoon, attached \\
\hline 21. Codium species & Nainativu & Inshore waters, floating \\
\hline 22. Acetabularia crenulata & Casuarina & $\begin{array}{l}\text { Protected inshore waters, } \\
\text { attached. }\end{array}$ \\
\hline 23. Chaetomorpha species & Mandaitivu & Lagoon, floating \\
\hline 24. Ulva reticulata & Mandaitivu & $\begin{array}{l}\text { Lagoon grows intermingled } \\
\text { with other algae }\end{array}$ \\
\hline 25. Ulva lactuca & Mandaitivu & Lagoon \\
\hline 26. Valoniopsis pachynema & Mandaitivu & Lagoon \\
\hline 27. Thalasia hemprichi & Mandaitivu & Coral lagoon, rooted \\
\hline
\end{tabular}


TABle 2. Iodine contents of Marine Algae

Algae Locality $\quad \begin{array}{ll}\text { Date of } \\ \text { collection }\end{array} \quad \begin{aligned} & \text { Moisture in the } \\ & \text { air-dried algae (\%) } \\ & \text { (washed) }\end{aligned}$

lodine (ppm) i.e. $\mathrm{mg}$ of iodine/kg air-dried algae
Washed

\section{a) Family: Rhadophyceae}

01. Gracilaria opuntia

02. Gracilaria edulis

03. Gracilaria crassa

04. Gracilaria confervoides

05. Laurencia obtusa

06. Jania natalensis

07. Hypnea musciformis

08. Acanthophora delile

09. Centroceras clavulatum

10. Gelidiella acerosa

b) Family: Phaeophyceae

14. Padina pavonica

15. Turbinaria ornata

13. Pocockiella variegata

14. Stoechospermum marginatum

15. Cystophyllum muricatum

16. Dictyota sp.

17. Sargassum tenerrimum

18. Sargassum polycystum

19. Hormophysa triquetra

c) Family: Chlorophyceae

20. Struvea anastamosans

21. Codium sp.

22. Acetabularia crenulata

23. Chaetomorpha sp.

24. Ulva reticulata

25. Ulva lactuca

26. Valoniopsis pachynema

d) Angiosperm

27. Thalasia hemprichi

$\begin{array}{ll}\text { Mandaitivu } & 10.12 .1982 \\ \text { Mandaitivu } & 10.12 .1982 \\ \text { Nainativu } & 01.01 .1983 \\ \text { Mandaitivu } & 10.12 .1982 \\ \text { Keerimalai } & 13.02 .1983 \\ & \\ \text { Mandaitivu } & 10.12 .1982 \\ \text { Mandaitivu } & 10.12 .1982 \\ \text { Mandaitivu } & 10.12 .1982 \\ \text { Mandaitivu } & 13.02 .1983 \\ \text { Keerimalai } & 13.02 .1983 \\ \text { Mandaitivu } & 31.12 .1982 \\ \text { Keerimalai } & 13.02 .1983 \\ \text { Mandaitivu } & 31.12 .1982\end{array}$

Mandaitivu 10.12.1982

Mandaitivu 31.12.1982

Nainativu 01.01.1983

Mandaitivu 13.02.1983

Mandaitivu 13.02.1983

Mandaitivu 13.02.1983

Mandaitivu 10.12.1982

Mandaitivu 31.12.1982

Mandaitivu 13.02 .1983

Mandaitivu 31.12 .1982

Nainativu 01.01.1983

Casuarina 13.02.1983

Nainativu $\quad 01.01 .1983$

Keerimalai 13.02.1983

Mandaitivu 10.12.1982

Mandaitivu 31.12.1982

Nainativu 01.01 .1983

Mandaitivu 10.12.1982

$\begin{array}{ll}\text { Casuarina } & \text { 25.12.1982 }\end{array}$

Keerimalai 13.02.1983

Mandaitivu 10.12 .1982

Mandaivitu $\quad 10.12 .1982$

Nainativu 01.01.1983
24.4

3.7

13.9

13.3

10.1

15.1

3.2

13.5

15.9

10.0

16.7

8.1

14.1

11.1

19.4

13.4

13.1

13.8

7.1

16.0

17.1

13.3

12.2

16.4

4.7

17.3

4.5

17.9

20.6

20.9

12.7

16.4

14.8

2.8

16.4

9.2
1277

318

134

889

no detectable

amount

421

101

277

115

110

249

133

524

147

no detectable amount

78

351

401

56

253

180

62

62

73

no detectable amount

80

no detectable amount

24

14

no detectable amount

30

178

54 
TABLE 3. Iodine content in sea-water samples

\begin{tabular}{lll} 
Locality & $\begin{array}{l}\text { Date of } \\
\text { collection }\end{array}$ & $\begin{array}{l}\text { Iodine } \\
(\mathrm{mg} / \text { litre })\end{array}$ \\
\hline Mandaitivu & 10.12 .1982 & 0.876 \\
Mandaitivu & 11.01 .1983 & 0.738 \\
Keerimalai & 19.01 .1983 & 0.067 \\
Nainativu & 23.01 .1983 & 0.054 \\
\hline
\end{tabular}

TABLE 4. Iodine contents reported 8 of some algae from the Gujarat coast of India

\begin{tabular}{lc}
\hline Species & $\begin{array}{l}\text { Iodine contents in } \\
p p m(m g / k g)\end{array}$ \\
\hline Ulva lactuca & 19.86 \\
Ulva rigida (C.A. Agardh) & 40.94 \\
Codium dwarkense Boergesen & 50.5 \\
Sargassum cinereum (J.Agar) & 206.1 \\
Sargassum johnstonii setch and Gard & 244.6 \\
Gracilaria folifera & 151.8 \\
Myriogloea sciuru (Harv.) Kuck & 1045.00
\end{tabular}

\section{Acknowledgements}

The authors wish to thank Prof. S. Balasubramaniam (Department of Botany, University of Peradeniya) and Dr. A. Sivapalan and Mr. A. M. T. Savarimuthu (Department of Botany, University of Jaffna) for their help in plant collection and identification. This work was supported by financial assistance from the Natural Resources, Energy and Science Authority of Sri Lanka.

\section{References}

1. (a) Answers to Iodine questions, published by Chilean Iodine Educational Bureau, Stone House, London E.C. 2.

(b) Encyclopedia Britannica, Micropeedia Volume V, pp. 407-408.

(c) Ibid Volume IX pp. 991-992.

(d) Encyclopedia Americana Volume 15, p. 344.

(e) Ibid Volume 26, pp. 715-716.

2. JАСОВ, M. B. (1958). The Chemical Analysis of foods and food products D. Van Nostrand Co., New York. 
3. Kappanna, A. N. \& RAo, V. S. (1962), J. Sci. and Indian Res. 21 B 559 and references cited therein.

4. Mageswaran, R., Sivasubramaniam, S. \& Somasundaram, K. (1983). Proc. Inst. Chem. Cey. 12.

5. Pillai, V. K. (1956). Proc. Indian Acad. Sci. 44B 3.

6. Russel, F. S. \& Yonge, C. M. (1960). The Seas, Fredrick Warne and Co., Ltd. London and New York, 359.

7. Thivy, F. Proc. Symp. Algology ICAR, New Delhi, pp. 345-365.

8. Vinogradove, A. P. (1953). Elementary Chemical Composition of Marine Organisms Memoir 11. Sears Foundation for Marine Research. Yale University, New Haves.

9. Wright, Samson (1978). Applied Physiology (12th Edition) revised by Cyril A. Keele and Eric Neil, Oxford University Press pp. 510-518. 